\title{
Pola Asuh Orang Tua dan Disiplin Belajar Daring Terhadap Hasil Belajar di Masa New Normal
}

\section{Kadek Dwi Narayani1*, I Nyoman Laba Jayanta ${ }^{2}$, Luh Putu Putrini Mahadewi3}

\author{
1,2 Prodi Pendidikan Guru Sekolah Dasar, Universitas Pendidikan Ganesha, Singaraja, Indonesia \\ ${ }^{3}$ Prodi Teknologi Pendidikan, Universitas Pendidikan Ganesha, Singaraja, Indonesia
}

\section{ART I C L E I N F O}

\section{Article history:}

Received July 14, 2021

Revised July 30, 2021

Accepted August 14, 2021

Available online October 25, 2021

Kata Kunci:

Pola Asuh, Disiplin, Hasil Belajar

Keywords:

Parenting, Discipline, Learning Outcomes

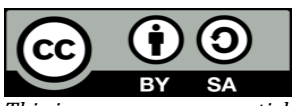

This is an open access article under the $\mathrm{CC}$ BY-SA license.

Copyright (ㄷ) 2021 by Author. Published by Universitas Pendidikan Ganesha.

\begin{abstract}
A B S T R A K
Hasil belajar siswa mulai menurun di masa pandemi COVID-19. Hal tersebut dipengaruhi oleh rendahnya disiplin siswa serta kurangnya perhatian orang tua di masa pandemi COVID-19. Tujuan penelitian ini untuk menganalisis hubungan pola asuh orang tua dan disiplin belajar terhadap hasil belajar dimasa new normal. Jenis penelitian ini adalah penelitian ex post facto. Populasi dalam penelitian ini adalah seluruh siswa dan orang tua kelas IV SD yang berjumlah 79 orang. Teknik pengambilan sampel yang digunakan adalah teknik sampling total, hal ini dikarenakan jumlah populasi kurang dari 100 orang sehingga populasi secara keseluruhan dijadikan sampel sebanyak 79 orang. Metode yang digunakan dalam mengumpulkan data yaitu metode kuesioner dan dokumen. Instrumen yang digunakan untuk mengumpulkan data yaitu kuesioner. Teknik analisis data yang digunakan yaitu analisis statistik deskriptif dan analisis statistik inferensial. Berdasarkan hasil analisis maka terdapat hubungan yang signifikan pola asuh orang tua dengan hasil belajar dengan nilai sebesar 0,547 atau kontribusinya sebesar 54,7\% sehingga terdapat hubungan yang signifikan peran orang tua dengan hasil belajar di masa new normal. Terdapat hubungan yang signifikansi disiplin belajar terhadap hasil belajar di masa new normal dengan nilai sebesar 0,421 atau kontribusinya sebesar $42,1 \%$. Hasil belajar dipengaruhi oleh pola asuh orang tua dan disiplin belajar diperoleh sebesar 0,597 atau kontribusinya sebesar $59,7 \%$. Jadi, terdapat hubungan yang signifikan pola asuh orang tua dan disiplin belajar daring terhadap hasil belajar di masa new normal. Implikasi penelitian ini yaitu pola asuh orang tua dan disiplin belajar sangat penting untuk meningkatkan hasil belajar siswa di masa new normal.
\end{abstract}

\section{A B S T R A C T}

Student learning outcomes began to decline during the COVID-19 pandemic. This is influenced by the low discipline of students and the lack of attention from parents during the COVID-19 pandemic. The purpose of this study was to analyze the relationship between parenting and learning discipline on learning outcomes in the new normal. This type of research is ex post facto research. The population in this study were all students and parents of fourth grade elementary school, totaling 79 people. The sampling technique used is a total sampling technique, this is because the total population is less than 100 people so that the overall population is used as a sample of 79 people. The method used in collecting data is the method of questionnaires and documents. The instrument used to collect data is a questionnaire. The data analysis technique used is descriptive statistical analysis and inferential statistical analysis. Based on the results of the analysis, there is a significant relationship between parenting and learning outcomes with a value of 0.547 or a contribution of $54.7 \%$ so that there is a significant relationship between the role of parents and learning outcomes in the new normal period. There is a significant relationship between learning discipline and learning outcomes in the new normal period with a value of 0.421 or a contribution of $42.1 \%$. Learning outcomes are influenced by parenting and learning discipline obtained by 0.597 or the contribution of $59.7 \%$. So it was found that there was a significant relationship between parenting and online learning discipline on learning outcomes in the new normal period. The implication of this research is that parenting and learning discipline are very important to improve student learning outcomes in the new normal period.

\section{PENDAHULUAN}

Pandemi Covid-19 menghambat berbagai aktivitas kegiatan masyarakat. Pemerintah mengeluarkan kebijakan new normal untuk mengatasi penyebaran virus COVID-19 yang berdampak terhadap sektor pendidikan (Dewi, 2020; Herliandry, Devi ., 2020; Mastura dan Rustan Santaria, 2020). Kegiatan pembelajaran yang biasanya dilaksanakan secara tatap muka beralih menjadi pembelajaran secara daring (dalam jaringan) dengan memanfaatkan teknologi dan jaringan internet (Marom, 2020; Zhang et al., 2020). Pembelajaran daring merupakan pembelajaran dengan memanfaatkan internet dan 
teknologi sehingga proses pembelajaran dapat terjadi (Yudi Firmansyah \& Fani Kardina, 2020). Pembelajaran daring dapat berlangsung dengan memanfaatkan berbagai aplikasi, seperti: zoom, google classroom, whatsapp, dan aplikasi lainnya sehingga tetap terjadi interaksi antara siswa dan guru (Firmansyah, 2020). Dengan menggunakan berbagai aplikasi diharapkan dapat meningkatkan hasil belajar siswa selama pembelajaran daring. Hasil belajar merupakan kemampuan yang diperoleh siswa setelah melakukan proses belajar dalam waktu tertentu dengan tujuan mengetahui tingkat keberhasilan yang dicapai siswa (Handayani \& Subakti, 2020; Mulyawati et al., 2019). Hasil belajar dijadikan sebagai patokan dalam menentukan keberhasilan siswa menguasai dan memahami suatu kompetensi yang diukur dengan nilai tes (Wei et al., 2021; Widiana, 2016; Wua et al., 2021).

Namun pada kenyataanya saat ini masih banyak siswa yang memiliki hasil belajar yang cukup rendah (Dafit, 2017; Jundu et al., 2020; Lusidawaty et al., 2020). Disamping itu pula, pembelajaran daring menyebabkan orang tua kesulitan memberikan fasilitas yang memadai kepada anaknya untuk menunjang dalam melaksankana pembelajaran (Asmuni, 2020; Dewi, 2020; Putria, 2020). Permasalahan tersebut terjadi pada siswa kelas IV SD Gugus IV di Kecamatan Mengwi. Berdasarkan hasil observasi dan wawancara yang dilakukan bersama 4 orang guru wali kelas IV SD Gugus IV di Kecamatan Mengwi Kabupaten Badung diketahui bahwa selama proses pembelajaran dilaksanakan secara daring, terdapat beberapa orang tua yang menerapkan pola asuh yang tidak tepat serta kurangnya perhatian dan pendampingan orang tua dalam pendidikan anak. Hal ini menyebabkan anak menjadi tidak disiplin dalam mengikuti pembelajaran daring, seperti tidak mengirimkan tugas tepat waktu dan tidak mendengarkan arahan yang diberikan oleh guru, serta tidak menunjukkan kesiapan dalam belajar. Siswa yang memiliki kendala dalam belajar disebabkan karena kurang baiknya pola asuh orang tua, sehingga hal tersebut menyebabkan anak tidak mengerjakan tugas yang diberikan guru yang mengakibatkan turunnya hasil belajar anak (Saya, 2020).

Upaya yang dapat dilakukan untuk mengatasi hal tersebut yaitu dengan menerapkan berbagai faktor, karena hasil belajar siswa dapat dipengaruhi oleh berbagai faktor, terutama faktor dari orang tuanya. Salah satu faktor yang mempengaruhi hasil belajar siswa adalah pola asuh orang tua dan disiplin belajar daring. Pola asuh orang tua merupakan interaksi antara orang tua dan anak pada aktivitas pengasuhan (Harianti, 2016; Hisby \& Kosasih, 2020). Orang tua menjadi tempat utama bagi peserta didik memperoleh pendidikan, sikap dan perhatian orang tua akan membantu siswa dalam memahami diri sehingga akan membantu meningkatkan semangat belajar siswa (Mirzaei \& Kadivarzare, 2014; Monge et al., 2021; Pada, 2021; Santosa et al., 2018). Selain itu pola asuh yang tepat akan meningkatkan keyakinan diri pada siswa sehingga akan mempengaruhi hasil belajar (Diah Fitasari et al., 2019; Kuppens \& Ceulemans, 2019; Syahrul \& Nurhafizah, 2021). Setiap orang tua memiliki pola pengasuhan yang berbedabeda, dengan pola pengasuhan yang berbeda akan membentuk karakter yang berbeda pada masingmasing anak (Putri \& Rustika, 2019; Santosa et al., 2018). Hal ini menunjukkan pengasuhan orang tua dinilai memiliki peranan yang sangat penting dalam setiap proses pembelajaran yang dilakukan anak. Selain pola asuh orang tua, disiplin penting dimiliki oleh siswa selama melaksanakan pembelajaran dari rumah (secara daring). Disiplin belajar merupakan sikap dan tingkah laku siswa yang ditunjukkan dalam menjalankan kewajibannya untuk belajar, baik belajar di rumah maupun belajar di sekolah (Handayani \& Subakti, 2020; Nugraheni, 2019). Disiplin belajar menekankan pada perubahan perilaku sebagai hasil dari pengalaman mengamati, membaca, menirukan, mendengarkan, serta mengikuti arahan atas ketaatan dan kepatuhan seseorang terhadap peraturan (L.Thompson et al., 2021; Novalinda et al., 2020; Octaviani, 2020) (Sugiarto et al., 2019). Siswa yang memiliki disiplin belajar yang baik akan melaksanakan kegiatan pembelajaran dengan baik, sehingga tujuan pembelajaran dapat tercapai dengan baik. Penelitian serupa juga menyatakan bahwa bahwa pola asuh orangtua dapat membantu siswa dalam belajar sehingga dapat meningkatkan pembelajaran daring (Daheri et al., 2020; Yulianingsih et al., 2020). Penelitian ini sejalan dengan penelitian yang menyatakan bahwa ditemukan hubungan positif antara pola asuh orang tua dan hasil belajar siswa (Hisby \& Kosasih, 2020; Pucangan, 2017; Rizki et al., 2017). Hubungan yang positif antara disiplin belajar dan hasil belajar (Handayani \& Subakti, 2020; Saya, 2020). Tujuan Penelitian ini adalah untuk menganalisis pola asuh orang tua, disiplin belajar daring terhadap hasil belajar siswa dimasa new normal. Diharapkan penelitian ini dapat membangkitkan meningkatkan hasil belajar siswa di masa pandemi Covid-19.

\section{METODE}

Penelitian ini dilaksanakan di SD gugus IV di Kecamatan Mengwi Tahun Pelajaran 2020/2021. Penelitian ini merupakan penelitian Ex-post facto, karena upaya pendekatan terhadap gejala penelitian dilakukan secara wajar apa adanya tanpa melakukan manipulasi terhadap gejala yang diteliti. Ex-post fakto merupakan penelitian dimana peniliti tidak melakukan pengendalian (kontrol) terhadap variabel 
bebas secara langsung, karena perwujudan variabel tersebut pada dasarnya memang tidak dapat dimanipulasi. Jenis penelitian ini adalah korelasi atau hubungan. Populasi dalam penelitian ini adalah seluruh siswa dan orang tua kelas IV SD Gugus IV di Kecamatan Mengwi yang berjumlah 79 orang yang terdiri dari 46 orang siswa laki-laki dan 33 orang siswa perempuan. Teknik pengambilan sampel yang digunakan dalam penelitian ini adalah teknik sampling total, hal ini dikarenakan jumlah populasi kurang dari 100 orang sehingga populasi secara keseluruhan dijadikan sampel sebanyak 79 orang. Sampel diambil dari empat sekolah, yaitu SD Negeri 1 Penarungan yang terdiri dari 9 siswa laki-laki dan 5 siswa perempuan, SD Negeri 2 Penarungan yang terdiri dari 17 siswa laki-laki dan 4 siswa perempuan, SD Negeri 3 Penarungan yang terdiri dari 11 siswa laki-laki dan 16 siswa perempuan, dan SD Negeri 4 Penarungan yang terdiri dari 9 siswa laki-laki dan 8 siswa perempuan. Adapun gambar konstalasi variabel penelitian ini ditunjukkan pada Gambar 1.

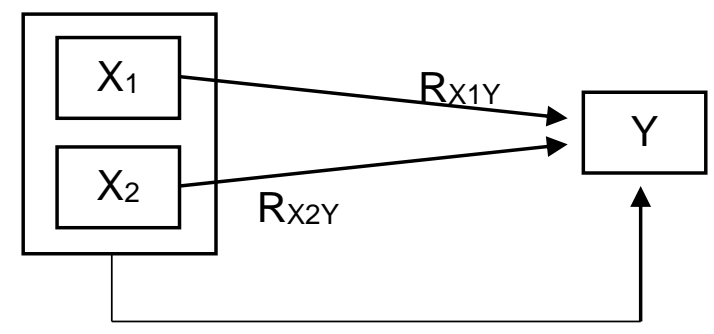

$R \times 1 \times 2 Y$

Keterangan:

$\mathrm{X}_{1} \quad=$ Pola Asuh Orang Tua

$\mathrm{X}_{2} \quad=$ Disiplin Belajar Daring

$\mathrm{Y} \quad=$ Prestasi Belajar

Rx1Y = Korelasi $X_{1}$ terhadap Y Subjek Penelitian

$\mathrm{R}_{\mathrm{X} 2 \mathrm{Y}}=$ Korelasi $\mathrm{X}_{2}$ terhadap $\mathrm{Y}$ Subjek Penelitian

$\mathrm{R}_{\mathrm{X} 1 \mathrm{X} 2 \mathrm{Y}}=$ Korelasi $\mathrm{X}_{1}$ dan $\mathrm{X}_{2}$ terhadap $\mathrm{Y}$ Subjek Penelitian

Metode pengumpulan data yang digunakan adalah metode kuesioner dan pencatatan dokumen. Dalam penelitian ini, instrumen yang digunakan dalam pengumpulan data adalah kuesioner pola asuh orang tua dan kuesioner disiplin belajar daring. Pencatatan dokumen dilakukan untuk mengetahui data prestasi belajar siswa dengan menggunakan nilai PTS (Penilaian Tengah Semester) siswa. Kuesioner pola asuh orang tua dibuat berdasarkan teori (Rizki et al., 2017) yang terdiri dari aspek pola asuh otoriter, pola asuh permisif, dan pola asuh demokratis yang berguna untuk mengukur sejauh mana pola asuh yang diterapkan orang tua kepada siswa kelas IV SD Gugus IV di Kecamatan Mengwi. Jumlah item kuesioner yang digunakan sebanyak 30 item. Kuesioner pola asuh orang tua menggunakan skala pengukuran Skala likert. Adapun kisi-kisi yang digunakan dalam menyusun kuesioner disajikan pada Tabel 1. Kuesioner disiplin belajar daring yang terdiri dari aspek disiplin dalam menentukan strategi belajar, disiplin terhadap waktu, disiplin terhadap tugas, dan disiplin terhadap tata tertib yang berguna untuk mengukur tingkat disiplin belajar daring siswa kelas IV SD Gugus IV di Kecamatan Mengwi. Jumlah item kuesioner yang digunakan sebanyak 30 item. Kuesioner disiplin belajar daring menggunakan skala pengukuran Skala Likert. Adapun kisi-kisi yang digunakan dalam menyusun kuesioner disajikan pada Tabel 1 dan 2.

Tabel 1. Kisi-Kisi Kuesioner Pola Asuh Orang Tua

\begin{tabular}{|c|c|c|c|c|c|}
\hline \multirow{2}{*}{ No } & \multirow{2}{*}{ Aspek } & \multirow{2}{*}{ Indikator } & \multicolumn{2}{|c|}{ Nomor Butir } & \multirow{2}{*}{ Jumlah } \\
\hline & & & Positif & Negatif & \\
\hline \multirow{2}{*}{1} & \multirow{2}{*}{ Otoriter } & 1. Memberikan hukuman kepada anak & 1,2 & 7,9 & 4 \\
\hline & & 2. Memberikan tuntutan kepada anak & $3,5,6$ & 4,8 & 5 \\
\hline \multirow{2}{*}{2} & \multirow{2}{*}{ Permisif } & 1. Tidak memberikan bimbingan kepada anak & $10,11,12$ & 13,14 & 5 \\
\hline & & 2. Tidak adanya kontrol kepada anak & $15,16,17$ & 18,19 & 5 \\
\hline \multirow{4}{*}{3} & \multirow{3}{*}{ Demokratis } & 1. Bersikap peduli kepada anak & $20,21,22$ & 23,24 & 5 \\
\hline & & $\begin{array}{l}\text { 2. Menanamkan sikap tanggung jawab kepada } \\
\text { anak }\end{array}$ & 25,26 & 27 & 3 \\
\hline & & 3. Sering berdiskusi dengan anak & 28,29 & 30 & 3 \\
\hline & & $\begin{array}{ll}\text { Jumlah } \\
\end{array}$ & & & 30 \\
\hline
\end{tabular}


Tabel 2. Kisi-Kisi Disiplin Belajar Daring

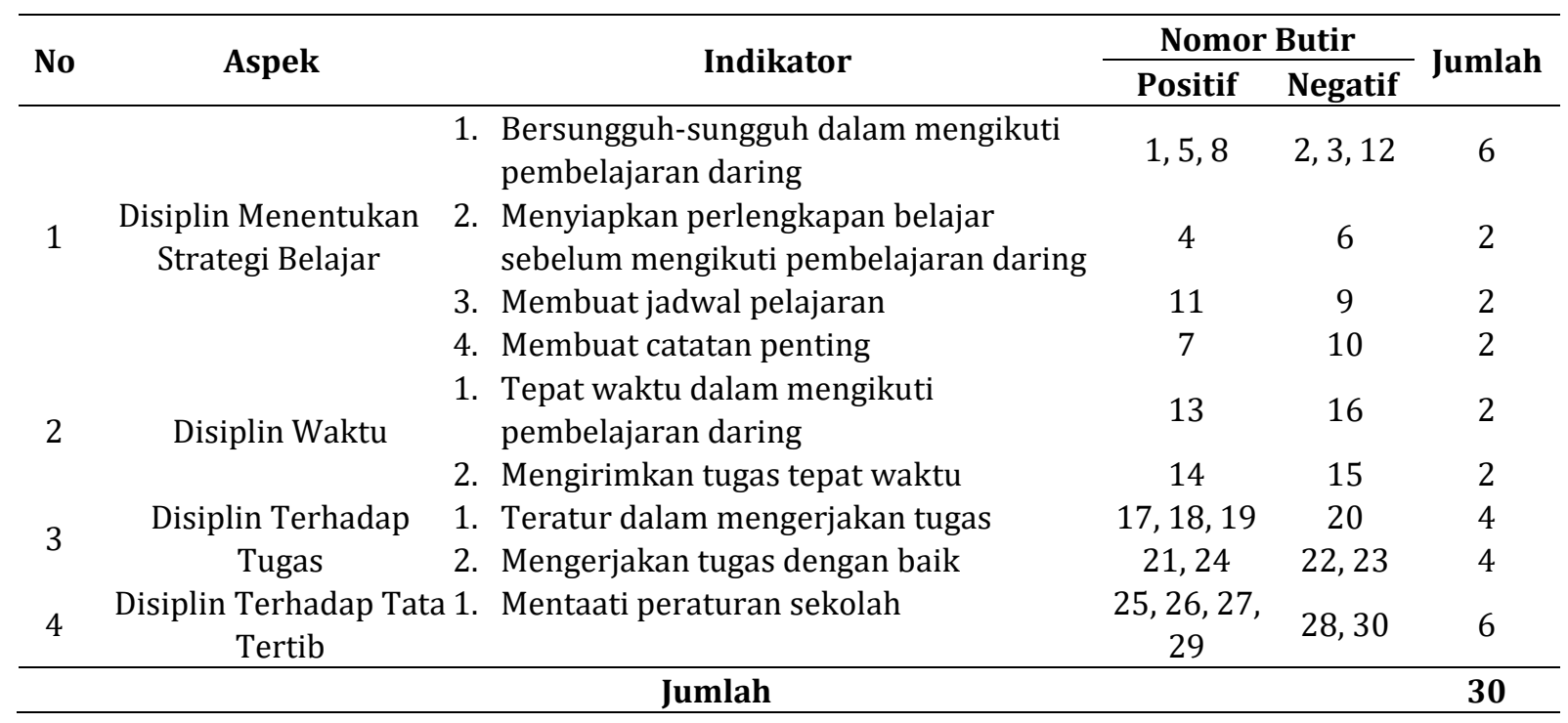

Pencatatan dokumen digunakan untuk mengumpulkan data hasil belajar siswa. Untuk memperoleh skor atau nilai dari variabel hasil belajar siswa sebagai variabel terikat dilakukan dengan perhitungan nilai rata-rata PTS (penilaian tengah semester). Sebelum melakukan penyebaran instrumen terlebih dahulu dilakukan pengujian instrumen, yaitu menentukan uji validitas dan uji reliabilitas. Uji validitas yang digunakan adalah uji validitas isi yang dilakukan melalui penilaian pakar (judges) dan uji validitas butir dengan menggunakan korelasi product moment. Uji validitas isi dilakukan dengan dua pakar yang menyatakan bahwa 60 item kuesioner dinyatakan valid dengan validitas sangat tinggi. Uji coba instrument dilakukan di SDN 1 Sibanggede dengan 30 responden yang memperoleh hasil bahwa secara keseluruhan butir instrument pola asuh orang tua dan disiplin belajar daring dinyatakan valid. Selanjutnya dilakukan uji reliabilitas menggunakan rumus Alpha Cronbach. Uji reliabilitas instrumen pola asuh orang tua dengan nilai Cronbach's Alpha $>\mathrm{r}_{\text {tabel }}(0,858>0,361)$ yang berarti instrumen pola asuh orang tua dikatakan reliabel dengan kategori reliabilitas sangat tinggi. Uji reliabilitas instrumen disiplin belajar daring dengan nilai Cronbach's Alpha $>$ rtabel $(0,944>0,361)$ yang berarti instrument disiplin belajar daring dikatakan reliabel dengan kategori sangat tinggi.

Teknik analisis data yang digunakan adalah teknik analisis statistik deskriptif dan analisis inferensial. Teknik analisis meliputi uji prasyarat analisis dan uji hipotesis. Uji prasyarat analisis yang digunakan dalam penelitian ini adalah uji normalitas, uji linieritas, uji multikolinearitas, uji autokorelasi, dan uji heterokedastisitas. Uji normalitas yang digunakan dalam penelitian ini, yaitu uji normalitas dengan teknik Kolmogorov-Smirnow dengan bantuan SPSS 16.0 untuk mengetahui kenormalan data. Uji linearitas digunakan untuk mengetahui apakah variabel bebas $(X)$ dan variabel terikat (Y) memiliki hubungan linear atau tidak. Uji multikolinieritas digunakan untuk mengetahui ada tidaknya hubungan antara dua variabel atau lebih dalam model regresi berganda. Uji heterokedastisitas digunakan untuk mengetahui ada tidaknya kesamaan varians residual dalam pengamatan yang dilakukan. Dalam penelitian ini, pengujian heterokedastisitas dilakukan dengan uji Glejser dibantu dengan SPSS 16.0. Uji autokorelasi dilakukan untuk mengetahui adanya hipotesi, artinya korelasi antar residu dalam suatu pengamatan, residual. Pengujian hipotesis dilakukan dengan uji regresi sederhana atau korelasi product moment dan analisis regresi ganda yang berfungsi untuk mencari makna korelasi anatar variabel X terhadap Y.

\section{HASIL DAN PEMBAHASAN}

\section{Hasil}

Deskripsi data hasil penelitian memaparkan rata-rata (mean), nilai tengah (median), nilai yang sering muncul (modus), varian, standar deviasi, skor minimum, skor maksimum, dan jangkauan. Hasil uji normalitas sebaran data untuk variabel pola asuh orang tua terhadap hasil belajar adalah 0,894. Nilai yang diperoleh tersebut lebih besar dari taraf signifikansi 5\% $(0,894>0,05)$. Sehingga dapat disimpulkan bahwa variabel pola asuh orang tua terhadap hasil belajar berdistribusi normal. Hasil uji normalitas sebaran data untuk variabel disiplin belajar daring terhadap hasil belajar adalah 0,179. Nilai yang diperoleh tersebut lebih besar dari taraf signifikansi $5 \%(0,179>0,05)$. Sehingga dapat disimpulkan 
bahwa variabel disiplin belajar daring terhadap prestasi belajar berdistribusi normal. Hasil uji normalitas sebaran data untuk variabel pola asuh orang tua dan disiplin belajar daring terhadap hasil belajar adalah 0,953 . Nilai yang diperoleh tersebut lebih besar dari taraf signifikansi $5 \%(0,953>0,05)$. Sehingga dapat disimpulkan bahwa variabel pola asuh orang tua dan disiplin belajar daring terhadap hasil belajar berdistribusi normal.

Hasil uji linearitas variabel pola asuh orang tua terhadap hasil belajar adalah 0,852 . Nilai yang diperoleh tersebut lebih besar dari taraf signifikansi $5 \%(0,852>0,05)$. Sehingga dapat disimpulkan bahwa terdapat hubungan yang linear variabel pola asuh orang tua terhadap hasil belajar. Hasil uji linearitas variabel disiplin belajar daring terhadap hasil belajar adalah 0,113. Nilai yang diperoleh tersebut lebih besar dari taraf signifikansi 5\% $(0,113>0,05)$. Sehingga dapat disimpulkan bahwa terdapat hubungan yang linear variabel disiplin belajar daring terhadap hasil belajar. Hasil uji multikolinearitas menunjukkan bahwa nilai tolerance sebesar 0,582, nilai tersebut mendekati 1 yang berarti 0,582 >0,10. Sedangkan nilai VIF sebesar 1,719 yang berarti 1,719<10, sehingga dapat disimpulkan bahwa tidak terjadi multikolinearitas variabel pola asuh orang tua dan disiplin belajar daring terhadap hasil belajar. Hasil uji heterokedastisitas menunjukkan bahwa nilai signifikansi (Sig.) untuk variabel pola asuh orang tua sebesar 0,406 yang berarti 0,406>0,05 dan nilai signifikansi variabel disiplin belajar daring sebesar 0,926 yang berarti $0,926>0,05$. Sehingga dapat disimpulkan bahwa regresi tidak mengandung gejala heterokedastisitas. Hasil uji autokorelasi menunjukkan bahwa koefisien Durbin-Watson besarnya 1,798 yaitu mendekati 2. Dengan demikian dapat disimpulkan bahwa regresi antara variabel bebas pola asuh orang tua dan disiplin belajar daring terhadap variabel terikat hasil belajar tidak terjadi autokorelasi.

Hasil uji hipotesis 1 menunjukkan bahwa uji signifikansi koefisien korelasi menggunakan tabel nilai $\mathrm{r}$ product moment untuk $\mathrm{N}=79$ pada taraf signifikansi $5 \%$. Nilai $\mathrm{r}_{\text {tabel }}$ untuk $\mathrm{N}=79$ pada taraf signifikansi $5 \%=0,221$. Dengan demikian, nilai $r_{\text {hitung }}>r_{\text {tabel }}(0,739>0,221)$. Maka kesimpulannya adalah $\mathrm{H}_{0}$ ditolak dan $\mathrm{H}_{a}$ diterima, yaitu terdapat korelasi yang signifikan pola asuh orang tua terhadap hasil belajar di masa new normal siswa kelas IV SD Gugus IV di Kecamatan Mengwi Tahun pelajaran 2020/2021. Koefisien determinasi (R Square) yang diperoleh sebesar 0,547 atau kontribusinya sebesar $54,7 \%$ variabel prestasi belajar ditentukan oleh pola asuh orang tua dan sisanya sebesar $45,3 \%$ disebabkan oleh faktor lainnya. Hasil uji hipotesis 2 menunjukkan bahwa uji signifikansi koefisien korelasi menggunakan tabel nilai $\mathrm{r}$ product moment untuk $\mathrm{N}=79$ pada taraf signifikansi $5 \%$. Nilai $\mathrm{r}_{\text {tabel }}$ untuk $\mathrm{N}=$ 79 pada taraf signifikansi $5 \%=0,221$. Dengan demikian, nilai $r_{\text {hitung }}>r_{\text {tabel }}(0,649>0,221)$. Maka kesimpulannya adalah $\mathrm{H}_{0}$ ditolak dan $\mathrm{H}_{\mathrm{a}}$ diterima, yaitu terdapat korelasi yang signifikan disiplin belajar daring terhadap hasil belajar di masa new normal siswa kelas IV SD Gugus IV di Kecamatan Mengwi Tahun Pelajaran 2020/2021. Koefisien determinasi (R Square) yang diperoleh sebesar 0,421 atau kontribusinya sebesar 42,1\% variabel hasil belajar ditentukan oleh disiplin belajar dan sisanya sebesar 57,9\% disebabkan oleh faktor lainnya.

Hasil uji hipotesis 3 menunjukkan bahwa uji signifikansi koefisien korelasi menggunakan tabel nilai $\mathrm{r}$ product moment untuk $\mathrm{N}=79$ pada taraf signifikansi $5 \%$. Nilai $\mathrm{r}_{\text {tabel }}$ untuk $\mathrm{N}=79$ pada taraf signifikansi $5 \%=0,221$. Dengan demikian, nilai rhitung $>r_{\text {tabel }}(0,773>0,221)$. sehingga dapat disimpulkan bahwa $\mathrm{H}_{0}$ ditolak dan $\mathrm{H}_{\mathrm{a}}$ diterima, yaitu terdapat korelasi yang signifikan secara simultan pola asuh orang tua dan disiplin belajar daring terhadap hasil belajar di masa new normal siswa Kelas IV SD Gugus IV di Kecamatan Mengwi Tahun Pelajaran 2020/2021. Koefisien determinasi digunakan untuk mengukur atau menjelaskan besarnya presentasi kontribusi variabel bebas $\left(\mathrm{X}_{1}, \mathrm{X}_{2}\right)$ terhadap naik turunnya nilai variabel terikat (Y), sedangkan selisish dari 100\% merupakan pengaruh yang tidak diteliti. Koefisien determinasi yang diperoleh adalah $\mathrm{R}_{\text {square }}=0,597$ atau kontribusinya sebesar 59,7\% variabel hasil belajar ditentukan oleh pola asuh orang tua dan disiplin belajar daring dan sisanya sebesar $40,3 \%$ dipengaruhi oleh faktor lain diluar penelitian. Data hasil penelitian disajikan pada Tabel 3.

Tabel 3. Deskripsi Data Pola Asuh Orang Tua, Disiplin Belajar Daring, dan Hasil Belajar

\begin{tabular}{ccccccccc}
\hline Variabel & Mean & Median & Modus & varian & $\begin{array}{c}\text { Standar } \\
\text { Deviasi }\end{array}$ & Skor min & $\begin{array}{c}\text { Skor } \\
\text { mak }\end{array}$ & Jangkauan \\
\hline $\begin{array}{c}\text { Pola } \\
\text { Asuh }\end{array}$ & 104,44 & 102,60 & 103,50 & 38,22 & 6,18 & 90 & 119 & 29 \\
$\begin{array}{c}\text { Orang } \\
\text { Tua }\end{array}$ & & & & & & & & \\
$\begin{array}{c}\text { Disiplin } \\
\text { Belajar }\end{array}$ & 124,12 & 121,86 & 121,30 & 158,79 & 12,60 & 87 & 150 & 63 \\
$\begin{array}{c}\text { Daring } \\
\text { Hasil } \\
\text { Belajar }\end{array}$ & 70,16 & 74,25 & 62,50 & 122,99 & 11,09 & 50 & 89 & 39 \\
\hline
\end{tabular}




\section{Pembahasan}

Hasil penelitian ini menemukan beberapa temuan yaitu, pertama menunjukkan fakta bahwa terdapat korelasi yang signifikan pola asuh orang tua terhadap hasil belajar di masa new normal siswa kelas IV SD Gugus IV di Kecamatan Mengwi. Hal ini membuktikan bahwa semakin tepat penerapan pola asuh orang tua maka semakin baik hasil belajar yang dicapai siswa. Pola asuh orang tua yang dapat meningkatkan hasil belajar siswa adalah pola asuh demokratis, karena pola asuh demokratis memberikan peraturan dan kebebasan kepada anak dalam menyampaikan keinginan, menunjukkan minat dan bakat anak sehingga anak tidak tertekan dalam mengikuti kegiatan pembelajaran yang berdampak pada pencapaian hasil belajar siswa (Hisby \& Kosasih, 2020; Rizki et al., 2017). Pola asuh demokratis memiliki sifat bebas sehingga anak dapat mengksplorasi bakat dan minatnya sehingga anak tidak mendapat tekanan (Sofiani \& Titin Mufika, 2020). Dorongan dan perhatian orang tua yang diberikan melalui pola asuh dapat meningkatkan keinginan anak dalam belajar dan dapat menunjang anak untuk mencapai hasil belajar yang tinggi (Lilawati, 2020; Yulianingsih et al., 2020). Sikap dan cara pengasuhan orang tua memiliki pengaruh yang besar terhadap hasil sekolah anak. Anak yang memperoleh pola asuh yang baik dari orang tua maka anak tersebut akan memiliki kebiasaan dan tingkah laku yang baik dalam lingkungan keluarga, sekolah, maupun masyarakat (Hisby \& Kosasih, 2020; Kurniati et al., 2020). Rata-rata pola asuh orang tua selama pembelajaran daring sudah baik, akan tetapi ada beberapa pola asuh orang tua yang kurang baik sehingga berdampak pada hasil belajar siswa. Hal tersebut berarti pola asuh orang tua memilki kaitan yang erat dengan hasil belajar siswa selama pembelajaran daring. Hasil temuan ini diperkuat dengan penelitian sebelumnya yang menyatakan bahwa semakin tinggi tingkat kepedulian dan perhatian orang tua akan mempermudah anak dalam mencapai hasil belajar (A'la \& Subhi, 2016; Luo et al., 2020).

Kedua menunjukkan bahwa terdapat hubungan yang signifikan disiplin belajar daring terhadap hasil belajar di masa new normal siswa kelas IV SD Gugus IV di Kecamatan Mengwi. Disiplin belajar di rumah saat ini penting dimiliki siswa, karena proses pembelajaran berlangsung secara daring (dalam jaringan) (Dewi et al., 2018; Radyuli \& Rahmat, 2017). Sikap disiplin yang dimiliki siswa akan membuat siswa terbiasa dan terlatih dalam mengambil tindakan, sehingga siswa akan mentaati tata tertib dan selalu patuh terhadap guru. Disiplin membuat siswa dapat mengontrol setiap tindakannya, sehingga siswa akan taat dan patuh terhadap tata tertib yang berlaku selama kegiatan belajar mengajar (Handayani \& Subakti, 2020). Siswa sudah menanamkan sikap disiplin baik di dalam rumah maupun di luar rumah sehingga siswa dapat mencapai hasil belajar yang optimal. Hal ini menunjukan disiplin belajar memberikan pengaruh positif terhadap hasil belajar. Disiplin belajar selama pandemi akan memberikan dampak pada kegiatan pembelajaran siswa (Anggraini et al., 2017; Dewi et al., 2018). Hal tersebut akan menimbulkan kebiasan atau keinginan untuk belajar, dengan kebiasaan belajar yang baik akan memberikan dampak pada hasil belajar siswa.

Ketiga menunjukkan bahwa terdapat korelasi yang positif dan signifikan secara simultan pola asuh orang tua dan disiplin belajar daring terhadap hasil belajar di masa new normal siswa kelas IV SD Gugus IV di Kecamatan Mengwi. Hal ini membuktikan bahwa pemilihan pola asuh yang tepat dapat membentuk anak yang bertanggung jawab akan pendidikannya sehingga anak mencapai hasil yang baik. Begitupula dengan disiplin belajar daring yang dimiliki siswa dapat meningkatkan hasil belajar siswa, karena siswa yang disiplin akan lebih cepat dalam memahami pelajaran yang diberikan oleh guru. Kesadaran orang tua dalam memperhatikan dan membimbing anak pada saat mengikuti pembelajaran daring dan kesadaran siswa akan pentingnya disiplin belajar di masa new normal sehingga siswa dapat mencapai hasil belajar yang tinggi. Orang tua berperan penting dalam pendidikan anak khusunya dalam hal memberikan bimbingan, kontrol terhadap anak, dan memperhatikan kebutuhan anak (Kurniati et al., 2020; Wisnu Budi Wijaya, 2019; Wua et al., 2021). Pola asuh demokratis lebih dominan diterapkan orang tua karena pola asuh akan membentuk anak yang bertanggung jawab, patuh, dan berorientasi pada hasil (Diah Fitasari et al., 2019).

Temuan penelitian ini diperkuat dengan penelitian sebelumnya menyatakan pola asuh orang tua sangat penting dalam pembelajaran daring (Hisby \& Kosasih, 2020; Pucangan, 2017; Saya, 2020; Yulianingsih et al., 2020). Temuan penelitian sebelumnya juga menyatakan bahwa orang tua memiliki peran dalam meningkatkan hasil belajar anak dimasa pandemi COVID-19 (Widyastuti et al., 2021). Keterkaitan antara pola asuh orang tua di masa pandemi COVID-19 dan disiplin belajar terhadap hasil belajar yang tidak dapat dipungkiri bahwa perbedaan pola asuh orang tua dalam mendampingi anak belajar akan menyebabkan tidak optimalnya hasil belajar anak. Implikasi penelitian ini yaitu peranan orang tua dalam memberikan pengaruhan sangat penting untuk meningkatkan hasil belajar pada siswa. Orang tua yang disiplin dalam membimbing anaknya ketika belajar, maka siswa akan memiliki disiplin belajar yang baik. Sebaliknya apabila orang tua tidak memperhatikan anaknya ketika sedang belajar karena sibuk bekerja, maka disiplin belajar anak akan berkurang. Sehingga akan mempengaruhi hasil 
belajar anak menjadi kurang optimal. Dari asumsi tersebut, maka hasil belajar siswa dipengaruhi oleh pola asuh orang tua dan disiplin belajar di masa pandemi COVID-19.

\section{SIMPULAN}

Terdapat hubungan yang signifikan antara pola asuh orang tua dan disiplin belajar terhadap hasil belajar siswa di masa pandemi covid-19. Direkomendasikan kepada orang tua untuk selalu memberikan pendampingan anak dalam belajar sehingga dapat meningkatkan hasil belajar anak.

\section{DAFTAR PUSTAKA}

A'la, R., \& Subhi, M. R. (2016). Perhatian Orang Tua Dan Motivasi Belajar Siswa. Jurnal Madaniyah, 1, 124142. https://journal.stitpemalang.ac.id/index.php/madaniyah/article/download/96/79/.

Anggraini, Y., Patmanthara, S., \& Purnomo. (2017). Pengaruh Lingkungan Belajar Dan Disiplin Belajar Terhadap Hasil Belajar Kompetensi Keahlian Elektronika Industri Di Sekolah Menengah Kejuruan. Jurnal Pendidikan: Teori, Penelitian, Dan Pengembangan, 2(2), 1650-1655. https://doi.org/10.17977/jptpp.v2i12.10316.

Asmuni, A. (2020). Problematika Pembelajaran Daring di Masa Pandemi Covid-19 dan Solusi Pemecahannya. Jurnal Paedagogy, 7(4), 281. https://doi.org/10.33394/jp.v7i4.2941.

Dafit, F. (2017). Pengaruh Model Pembelajaran Multiliterasi Terhadap Kemampuan Membaca Siswa Sekolah Dasar. Jurnal Inovasi Pendidikan Dan Pembelajaran Sekolah Dasar, 1(1), 87-100. https://doi.org/10.24036/jippsd.v1i1.7937.

Daheri, M., Juliana, J., Deriwanto, D., \& Amda, A. D. (2020). Efektifitas WhatsApp sebagai Media Belajar Daring. Jurnal Basicedu, 4(4), 775-783. https://doi.org/10.31004/basicedu.v4i4.445.

Dewi. (2020). Dampak COVID-19 terhadap Implementasi Pembelajaran Daring di Sekolah Dasar. Jurnal Edukatif Ilmu Pendidikan, 2(1). https://doi.org/10.31004/edukatif.v2i1.89.

Dewi, K. M. S., Suwatra, I. W., \& Suarjana, M. (2018). Kontribusi Disiplin Belajar dan Motivasi Berprestasi Terhadap Hasil Belajar Matematika. Jurnal Penelitian Dan Pengembangan Pendidikan, 2(2), 152. https://doi.org/10.23887/jppp.v2i2.15397.

Diah Fitasari, N. P., Suniasih, N. W., \& Sastra Agustika, G. N. (2019). Pengaruh Pola Asuh Orang Tua Terhdap Hasil Belajar Matematika dengan Efikasi Diri Sebagai Intervening. International Journal of Elementary Education, 3(4), 404. https://doi.org/10.23887/ijee.v3i4.21313.

Handayani, E. S., \& Subakti, H. (2020). Pengaruh Disiplin Belajar terhadap Hasil Belajar Bahasa Indonesia di Sekolah Dasar. Jurnal Basicedu, 5(1), 151-164. https://doi.org/10.31004/basicedu.v5i1.633.

Harianti, R. (2016). Pola Asuh Orangtua Dan Lingkungan Pembelajaran Terhadap Motivasi Belajar Siswa. Curricula, 2(2), 20-30. https://doi.org/10.22216/jcc.v2i2.983.

Herliandry, Devi ., N. M. E. S. H. K. (2020). Pembelajaran Pada Masa Pandemi Covid-19. Jurnal Pendidikan Teknologi, 22(1), 65-69. https://doi.org/10. 21009/jtp.v22i1.15286.

Hisby, M., \& Kosasih, E. (2020). Hubungan Pola Asuh Orang Tua Dengan Hasil Belajar Pkn Siswa SD Negeri 2 Caracas. EduBasic Journal: Jurnal Pendidikan Dasar, 2(1), 26-35. https://doi.org/10.17509/ebj.v2i1.26797.

Jundu, R., Tuwa, P., \& Seliman, R. (2020). Hasil Belajar IPA Siswa SD di Daerah Tertinggal dengan Penerapan Model Pembelajaran Inkuiri Terbimbing. Jurnal Pendidikan Dan Kebudayaan, 10(2), 103-111. https://doi.org/10.24246/j.js.2020.v10.i2.p103-111.

Kuppens, S., \& Ceulemans, E. (2019). Parenting Styles: A Closer Look at a Well-Known Concept. Journal of Child and Family Studies, 28(1), 168-181. https://doi.org/10.1007/s10826-018-1242-x.

Kurniati, E., Nur Alfaeni, D. K., \& Andriani, F. (2020). Analisis Peran Orang Tua dalam Mendampingi Anak di Masa Pandemi Covid-19. Jurnal Obsesi : Jurnal Pendidikan Anak Usia Dini, 5(1), 241. https://doi.org/10.31004/obsesi.v5i1.541.

L.Thompson, G., Combs, A. M., \& D.Jansen, M. (2021). Relationships between consultant discipline and specified tree diversity: A case study of two Iowa (USA) communities. Urban Forestry \& Urban Greening, 62, 127183. https://doi.org/10.1016/j.ufug.2021.127183.

Lilawati, A. (2020). Peran Orang Tua dalam Mendukung Kegiatan Pembelajaran di Rumah pada Masa Pandemi. Jurnal Obsesi: Jurnal Pendidikan Anak Usia Dini, 5(1), 549. https://doi.org/10.31004/obsesi.v5i1.630.

Luo, Y., Chen, F., Zhang, X., Zhang, Y., Li, Y., Zhou, Q., \& Wang, Y. (2020). Profiles of Maternal and Paternal Parenting Styles in Chinese Families: Relations to Preschoolers 02019; Psychological Adjustment. Children and Youth Services Review. https://doi.org/10.1016/j.childyouth.2020.105787.

Lusidawaty, V., Fitria, Y., Miaz, Y., \& Zikri, A. (2020). Pembelajaran Ipa Dengan Strategi Pembelajaran 
Inkuiri Untuk Meningkatkan Keterampilan Proses Sains Dan Motivasi Belajar Siswa Di Sekolah Dasar. Jurnal Basicedu, 4(1), 168-174. https://doi.org/10.31004/basicedu.v4i1.333.

Marom, K. (2020). Peran Orang Tua Dalam Membangun Motivasi Belajar Siswa Selama Pandemi Covid-19 $\mathrm{Di}$ Sd Islam Daarul Muwahidin Semarang. Webinar Series FIP, 28-35. http://conference.upgris.ac.id/index.php/wsfip/article/view/1313.

Mastura dan Rustan Santaria. (2020). Dampak Pandemi Covid-19 terhadap Proses Pengajaran bagi Guru dan Siswa. Jurnal Studi Guru Dan Pembelajaran, 3(2), 289-295. https://doi.org/10.30605/jsgp.3.2.2020.293.

Mirzaei, F., \& Kadivarzare, H. (2014). Relationship between Parenting Styles and Hardiness in High School Students. Procedia - Social and Behavioral Sciences, 116, 3793-3797. https://doi.org/10.1016/j.sbspro.2014.01.843.

Monge, R. R., Castro, V. S., O’Connor, T., Ramos, U. C., \& Benjamin Reyes Fernández. (2021). Intersectionality between parenting styles, area of residence and gender on food group consumption among Costa Rican adolescents. Appetite, 166, 105443. https://doi.org/10.1016/j.appet.2021.105443.

Mulyawati, Y., Sumardi, S., \& Elvira, S. (2019). Pengaruh Disiplin Belajar Terhadap Hasil Belajar Ilmu Pengetahuan Sosial. Pedagonal: Jurnal Ilmiah Pendidikan, 3(1), 01-14. https://doi.org/10.33751/pedagog.v3i1.980.

Novalinda, R., Prima, F. K., Mallisza, D., \& Ambiyar, A. (2020). Pengaruh Pembelajaran Berbasis Entrepreneurship Dan Disiplin Belajar Terhadap Hasil Belajar Manajemen Optik. Edukasi: Jurnal Pendidikan, 18(2), 192. https://doi.org/10.31571/edukasi.v18i2.1859.

Nugraheni, S. (2019). Hubungan Antara Motivasi Belajar Dengan Disiplin Belajar Siswa. Journal for Lesson and Learning Studies, 2(1), 30-36. https://doi.org/10.23887/jlls.v2i1.17317.

Octaviani, N. R. (2020). Pengaruh Pola Asuh Orang Tua dan Disiplin Belajar Terhadap Hasil Belajar PPKn Siswa Kelas V SDN Dabin I Kecamatan Tegal Selatan Kota Tegal. http://lib.unnes.ac.id/38583/.

Pada, A. (2021). Pengaruh Pola Asuh Orangtua Terhadap Hasil Belajar Siswa Kelas IV Sekolah Dasar. Jurnal Ilmiah Ilmu Kependidikan, 5(2), 375-386. https: //doi.org/10.26858/jkp.v5i2.20912.

Pucangan, K. dkk. (2017). Hubungan Antara Konsep Diri Dan Pola Asuh Orang Tua Terhadap Hasil Belajar IPA Siswa Kelas V SD di Desa Selat. Jurnal Mimbar PGSD Universitas Pendidikan Ganesha, 5(2), 110. https://doi.org/10.23887/jjpgsd.v5i2.11007.

Putri, N. L. P. N. I. A., \& Rustika, I. M. (2019). Peran pola asuh otoritatif dan internal locus of control terhadap kecerdasan emosional remaja madya di SMA Negeri 1 Tabanan. Jurnal Psikologi Udayana, 6(01), 56. https://doi.org/10.24843/jpu.2019.v06.i01.p06.

Putria, H. (2020). Analisis Proses Pembelajaran Dalam Jaringan (DARING) Masa Pandemi COVID-19 pada Guru Sekolah Dasar. Jurnal BASICEDU, 4(4), 861-872. https://doi.org/10.31004/basicedu.v4i4.460.

Radyuli, P., \& Rahmat, V. (2017). Korelasi Disiplin Belajar dan Kreativitas Belajar Terhadap Minat Belajar Teknologi Informasi dan Komunikasi ( TIK ). Jurnal Pendidikan Dan Teknologi Informasi, 4(2), 262-271. https://ejournal.undiksha.ac.id/index.php/JP2/article/view/37184.

Rizki, S. D., Susilawati, \& Mariam, I. (2017). Hubungan pola asuh orang tua dengan prestasi belajar anak usia sekolah dasar kelas ii dan iii. Jurnal Keperawatan, 8(1), 74-84. https: //ejournal.umm.ac.id/index.php/keperawatan/article/view/4020.

Santosa, A. I., Rafli, Z., \& Lustyantie, N. (2018). Pengaruh Pola Asuh Orang Tua dan Sikap Bahasa terhadap Kemampuan Membaca Pemahaman The Influence of Parenting Style and Language Attitude toward the Reading Comprehension Achievement. Jurnal Pendidikan Bahasa Dan Sastra, 18(April), 69-80. https://ejournal.upi.edu/index.php/BS_JPBSP/article/view/12147.

Saya, S. (2020). Pengaruh Pola Asuh Orang Tua Dan Disiplin Belajar Terhadap Prestasi Belajar Siswa. Jurnal Pendidikan Dan Bimbingan Konseling, 1(1), 1-6. https://ejurnal-mapalusunima.ac.id/index.php/educouns/article/view/98.

Sofiani, I. K., \& Titin Mufika. (2020). Bias Gender dalam Pola Asuh Orangtua pada Anak Usia Dini. Jurnal Obsesi: Jurnal Pendidikan Anak Usia Dini, 4(1), 766-777. https://doi.org/10.31004/obsesi.v4i2.300.

Sugiarto, A. P., Suyati, T., \& Yulianti, P. D. (2019). Faktor Kedisiplinan Belajar Pada Siswa Kelas X Smk Larenda Brebes. Mimbar Ilmu, 24(2), 232. https://doi.org/10.23887/mi.v24i2.21279.

Syahrul, \& Nurhafizah. (2021). Analisis Pengaruh Pola Asuh Orang Tua Terhadap Perkembangan Sosial dan Emosional Anak Usia Dini Dimasa Pandemi Corona Virus 19. Jurnal Basicedu, 5(2), 683-696. https://doi.org/10.31004/basicedu.v5i2.792.

Wei, X., Saab, N., \& Admiraala, W. (2021). Assessment of cognitive, behavioral, and affective learning outcomes in massive open online courses: A systematic literature review. Computers \& Education, 
163, 104097. https://doi.org/10.1016/j.compedu.2020.104097.

Widiana, I. W. (2016). Pengembangan Asesmen Proyek Dalam Pembelajaran IPA di Sekolah Dasar. JPI (Jurnal Pendidikan Indonesia), 5(2), 147. https: //doi.org/10.23887/jpi-undiksha.v5i2.8154.

Widyastuti, Kurniawan, S. B., \& Rintayati, P. (2021). Keterlibatan orang tua dalam pembelajaran daring selama pandemi covid-19 di sekolah dasar. Didaktika Dwija Indria, 9(449). https://jurnal.uns.ac.id/JDDI/article/view/48781.

Wisnu Budi Wijaya, I. K. (2019). Menanamkan Konsep Catur Paramita Pada Anak Usia Dini Di Lingkungan Keluarga Dan Sekolah. Pratama Widya: Jurnal Pendidikan Anak Usia Dini, 3(2), 41-46. https://doi.org/10.25078/pw.v3i2.737.

Wua, W., Wu, M.-Y., Yi, L., \& Lehto, X. (2021). Measuring Chinese adolescents' learning outcomes in family travel: A scale development approach. Journal of Destination Marketing \& Management, 20, 100617. https://doi.org/10.1016/j.jdmm.2021.100617.

Yudi Firmansyah, \& Fani Kardina. (2020). Pengaruh New Normal Ditengah Pandemi Covid-19 Terhadap Pengelolahan Sekolah Dan Peserta Didik. Buana Ilmu, 4(2), 99-112. https://doi.org/10.36805/bi.v4i2.1107.

Yulianingsih, W., Suhanadji, S., Nugroho, R., \& Mustakim, M. (2020). Keterlibatan Orangtua dalam Pendampingan Belajar Anak selama Masa Pandemi Covid-19. Jurnal Obsesi : Jurnal Pendidikan Anak Usia Dini, 5(2), 1138-1150. https: //doi.org/10.31004/obsesi.v5i2.740.

Zhang, W., Wang, Y., Yang, L., \& Wang, C. (2020). Suspending Classes Without Stopping Learning: China's Education Emergency Management Policy in the COVID-19 Outbreak. Journal of Risk and Financial Management, 13(3), 55. https://doi.org/10.3390/jrfm13030055. 